Design, Fabrication and Bench Testing of a Texaco Infrared Ratio Pyrometer System for the Measurement of Gasifier Reaction Chamber Temperature

\author{
Quarterly Report \\ Reporting Period Start Date: January 1, 2003 \\ Reporting Period End Date: March 31, 2003 \\ Principal Authors: Thomas F. Leininger, Hua-Min Huang
}

Report Issued: April 2003

DOE Award Number: DE-FC26-99FT40684

\begin{abstract}
Submitted by:
ChevronTexaco Worldwide Power and Gasification, Montebello Technology Center 329 North Durfee Avenue, South El Monte, CA 91733
\end{abstract}




\section{DISCLAIMER -}

This report was prepared as an account of work sponsored by an agency of the United States Government. Neither the United States Government nor any agency thereof, nor any of their employees, makes any warranty, express or implied, or assumes any legal liability or responsibility for the accuracy, completeness, or usefulness of any information, apparatus, product, or process disclosed, or represents that its use would not infringe privately owned rights. Reference herein to any specific commercial product, process, or service by trade name, trademark, manufacturer, or otherwise does not necessarily constitute or imply its endorsement, recommendation, or favoring by the United States Government or any agency thereof. The views and opinions of authors expressed herein do not necessarily state or reflect those of the United States Government or any agency thereof. 


\section{ABSTRACT -}

The cooperative agreement between Texaco and Polk Power has been revised by Polk Power and ChevronTexaco several times already. Lawyers from both Polk Power and ChevronTexaco are in the process to include the issues related to the ownership transfer of the Texaco gasification unit in the agreement and finalize the draft. The modification fieldwork and testing will start once the cooperative agreement is signed with Polk Power. 


\section{TABLE OF CONTENTS}

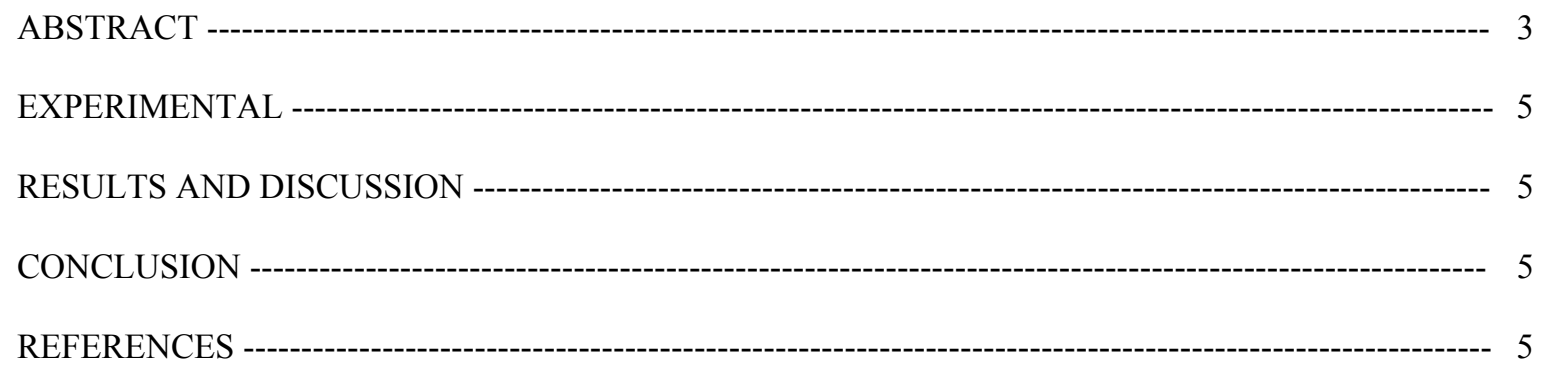




\section{EXPERIMENTAL -}

The cooperative agreement between Texaco and Polk Power has been revised by Polk Power and ChevronTexaco several times already. Lawyers from both Polk Power and ChevronTexaco are in the process to include the issues related to the ownership transfer of the Texaco gasification unit in the agreement and finalize the draft. The modification fieldwork and testing will start once the cooperative agreement is signed with Polk Power.

\section{RESULTS AND DISCUSSION -}

There are no test results in this reporting quarter.

\section{CONCLUSION -}

There are no conclusions in this reporting quarter.

\section{REFERENCES -}

None

Note: SI is an abbreviation for "Le Systeme International d'Unites." 